\author{
Anna Żyla \\ Politechnika Świętokrzyska \\ e-mail: azyla@tu.kielce.pl \\ ORCID: 0000-0001-5738-1033
}

\title{
WPLYW INICJATYWY NOWEGO JEDWABNEGO SZLAKU NA ATRAKCYJNOŚĆ INWESTYCYJNĄ KRAJÓW ASEAN
}

\section{THE INFLUENCE OF THE NEW SILK ROAD INITIATIVE ON INVESTMENT ATTRACTIVENESS OF ASEAN COUNTRIES}

DOI: $10.15611 / \mathrm{e} 21.2019 .1 .03$

JEL Classification: F02, F20, F21, F53, F63

Streszczenie: Celem niniejszego artykułu jest przedstawienie wpływu działań podejmowanych w ramach ogłoszonej przez Chiny w 2013 r. koncepcji Nowego Jedwabnego Szlaku na rozmiary inwestycji zagranicznych podejmowanych w krajach należących do Stowarzyszenia Narodów Azji Południowo-Wschodniej, a przez to na wzrost ich atrakcyjności inwestycyjnej. Artykuł składa się z dwóch części: teoretycznej oraz empirycznej. Część teoretyczna poświęcona została wyjaśnieniu pojęcia atrakcyjności inwestycyjnej, natomiast w części empirycznej zaprezentowano informacje i dane statystyczne wskazujące na wzrost atrakcyjności inwestycyjnej krajów ASEAN w związku z ich uczestnictwem w koncepcji Pasa i Szlaku. Podejmowane w nich inwestycje, w szczególności chińskie, mają przyczynić się przede wszystkim do rozbudowy infrastruktury i tym samym do zwiększenia zainteresowania inwestorów lokowaniem działalności w tym regionie.

Słowa kluczowe: Nowy Jedwabny Szlak, ASEAN, atrakcyjność inwestycyjna.

Summary: The purpose of this article is to analyze the impact of activities undertaken within the framework of the New Silk Road Initiative announced by China in 2013 on the size of foreign direct investment in countries belonging to the Association of Southeast Asian Nations, and thus to increase their investment attractiveness. The article is divided into two parts: theoretical and empirical. The theoretical part is devoted to the explanation of the definition of investment attractiveness, while in the empirical part, the information and statistical data were used to show the increase of investment attractiveness of ASEAN countries in connection with their participation in One Belt One Road Initiative. The investments which are located in ASEAN countries, in particular by Chinese, are concentraded especially in infrastructure to increase investors interests to this region.

Keywords: New Silk Road, ASEAN, investment attractiveness. 


\section{Wstęp}

One Belt One Road (OBOR) to inicjatywa, która od kilku lat budzi wiele emocji na arenie międzynarodowej. Przedstawiona w 2013 r. przez przewodniczącego Chińskiej Republiki Ludowej Xi Jinpinga idea reaktywacji starożytnego Jedwabnego Szlaku jest nie tylko próbą poprawy obecnych i nawiązania nowych relacji handlowych przez ten kraj, ale także, z czym zgadza się wielu badaczy, próbą stworzenia nowego międzynarodowego porządku ekonomicznego oraz politycznego na świecie, w którym Chiny odgrywać będą kluczową rolę. Celem tego projektu jest bowiem stworzenie platformy międzynarodowej współpracy przez rozwijanie więzi między jego uczestnikami - więzi zarówno ekonomicznych, jak i politycznych, instytucjonalnych, społecznych i kulturowych. Dzięki rosnącej współzależności między gospodarką chińską a krajami włączonymi do OBOR Chiny umocnią swoją pozycję w gospodarce globalnej. Szybkość podejmowanych działań oraz zakres i rozmiary już realizowanych inwestycji pokazują, że Nowy Jedwabny Szlak jest koncepcją dobrze przemyślaną, która traktowana może być jako pokojowa odpowiedź na amerykańską i rosyjską obecność, szczególnie w krajach azjatyckich, oraz na wpływy tych państw w Europie.

Omawiana koncepcja Pasa i Szlaku ma bez wątpienia przynieść korzyści Chińskiej Republice Ludowej. Zyskać mają jednak na niej także pozostałe kraje, które do niej przystąpią. Zgodnie z założeniami głoszonymi wielokrotnie przez Xi Jinpinga podczas wystąpień międzynarodowych popartych opublikowanym w $2015 \mathrm{r}$. dokumentem - Vision and Actions on Jointly Building Silk Road Economic Belt and 21st-Century Maritime Silk Road - współpraca w ramach tej koncepcji ma opierać się na formule win-win cooperation [Vision and Actions on Jointly...], dlatego też cieszy się ona dużą popularnością. W 2018 r. jej uczestnikami było już ok. 70 krajów na całym świecie. Jednakże należy podkreślić, że jest to inicjatywa stworzona przez Chiny, zatem skala możliwych do osiągnięcia korzyści przez pozostałe kraje zależy od umiejętności wykorzystania interesów chińskich w realizacji własnych celów [Behrendt 2017, s. 3]. Wymiernym wynikiem tejże współpracy ma być wzrost efektywności transportu (ograniczenie kosztów i czasu przewozu towarów), wzrost wymiany handlowej oraz inwestycji podejmowanych we wszystkich krajach, co z kolei przełożyć się ma na wzrost ich atrakcyjności inwestycyjnej.

\section{Teoretyczne ujęcie atrakcyjności inwestycyjnej}

Atrakcyjność inwestycyjna danego kraju jest bez wątpienia jedną z najistotniejszych zmiennych determinujących napływ kapitału na jego terytorium. Konieczność wyboru najkorzystniejszego miejsca lokalizacji działalności przez inwestorów zagranicznych wynika z potrzeby optymalizacji procesu produkcyjnego, którego celem jest maksymalizacja zysków oraz minimalizacja kosztów. Od oceny poziomu atrakcyjności dokonywanej przez inwestorów zależy zatem w dużej mierze sukces go- 
spodarczy państwa goszczącego. Liczba i jakość posiadanych przez nie przewag wpływa na stopień zainteresowania przedsiębiorców lokowaniem działalności na jego obszarze.

W literaturze istnieje wiele definicji atrakcyjności inwestycyjnej. Przez autorów rozumiana jest ona m.in. jako:

- „Zdolność skłonienia inwestorów do wyboru danego regionu jako miejsca lokalizacji inwestycji" [Gawlikowska-Hueckel, Umiński, 2000, s.7]. Zdolność ta jest z kolei pochodną kombinacji zalet (korzyści) lokalizacyjnych danego obszaru tzw. czynników lokalizacji. Za kraje atrakcyjne inwestycyjnie uznaje się te, które oferują optymalne połączenie czynników istotnych z punktu widzenia danego przedsiębiorstwa i rodzaju prowadzonej przez nie działalności.

- „Zdolność przyciągnięcia przez region inwestorów, zdolność kreowania szans rozwojowych dla podmiotów gospodarczych na danym obszarze" [Gołaszewska-Kaczan 2006, s. 545]. Zgodnie z tym ujęciem przedsiębiorca, który może ulokować działalność w dowolnym miejscu na świecie, wybierze to, w którym, jego zdaniem, istnieć będzie największe prawdopodobieństwo osiągnięcia sukcesu. Każdemu czynnikowi lokalizacji inwestor przypisuje zatem wagi. Waga danego czynnika w opinii różnych inwestorów może być jednak różna, co oznacza, że ten sam obszar może być atrakcyjny pod względem lokalizacji inwestycji dla jednego przedsiębiorcy, a dla innego już nie. Poza zachętami oferowanymi dla inwestorów i wynikającymi ze specyfiki regionu istotne znaczenie w procesie decyzyjnym ma również rodzaj prowadzonej działalności, a także subiektywna ocena dokonana przez samego inwestora - jego wiedza i doświadczenie, naciski ze strony otoczenia oraz obraz kształtowany i rozpowszechniany przez media.

- „Kombinacja korzyści lokalizacji możliwych do osiągnięcia w trakcie prowadzenia działalności gospodarczej i wynikających ze specyficznych cech obszaru, w którym działalność ma miejsce" [Kalinowski (red.) 2005, s. 9].

Często atrakcyjność inwestycyjna utożsamiana jest także z klimatem inwestycyjnym. Ten w literaturze definiowany jest $\mathrm{z}$ kolei m.in. jako:

- „całokształt działań państwa przyjmującego bezpośrednie inwestycje zagraniczne, zachęcających potencjalnych inwestorów zagranicznych do podjęcia inwestycji” [Witkowska 1996, s. 57],

- pojęcie, które ,informuje inwestora o stanie gospodarki kraju przyjmującego inwestycje, a także o stanie infrastruktury kraju oraz przyszłych długookresowych zmianach, które mogą wystąpić" [Stawicka 2007, s. 117].

Wielu autorów traktuje jednak o atrakcyjności inwestycyjnej przez pryzmat wspomnianych wcześniej czynników lokalizacji. Jedną z tego typu definicji przedstawia J. Czech-Rogosz: „czynniki lokalizacji to właściwości, które decydują o atrakcyjności inwestycyjnej miejsca lub regionu dla obecnych i potencjalnych przedsiębiorców, dające się podzielić na komplementarne względem siebie czynniki miękkie i czynniki twarde. Czynniki miękkie nie mają bezpośredniego wpływu 
na działalność przedsiębiorstwa, są trudno mierzalne (...). Natomiast twarde czynniki lokalizacyjne, wpływające na decyzje firmy, są łatwo kwantyfikowalne, a ich interpretacja nie znajduje się pod wpływem subiektywnej percepcji przedsiębiorcy" [Czech-Rogosz 2012, s. 266]. Do czynników świadczących o atrakcyjności inwestycyjnej danego obszaru odwoływali się już także: J. Tinbergen w 1962 r. oraz H. Linnemann w 1966 r. Zaobserwowali oni, że przepływy kapitału między regionami determinowane są przez wielkość i potencjał zagranicznego rynku, odległość od rynku macierzystego oraz przez bariery w prowadzeniu działalności w skali międzynarodowej [Kokkinou, Psycharis 2005, s. 5]. Z kolei zgodnie z podejściem zaproponowanym przez M.E. Portera przyciąganie międzynarodowych przedsiębiorstw opiera się przede wszystkim na zdolności do wzmacniania konkurencyjności gospodarki. Dokładniej czynniki, takie jak: sieci transportowe i komunikacyjne (tzw. infrastruktura fizyczna), wykwalifikowana siła robocza oraz możliwości kształcenia poparte obecnością strumienia odpowiedniej wiedzy, są kluczowe w wyborze miejsca lokalizacji działalności ${ }^{1}$. J.H. Dunning, odwołując się do czynników lokalizacji świadczących o atrakcyjności inwestycyjnej danego obszaru, wskazał z kolei motywy podejmowania bezpośrednich inwestycji zagranicznych. Wśród motywów tych wymienił: poszukiwanie zasobów, rynków zbytu, sposobów poprawy efektywności oraz aktywów strategicznych [Dunning 2000, s. 163-190].

Wielu autorów podejmuje próby identyfikacji czynników lokalizacji działalności. Według J. Komorowskiego przedsiębiorca rozważający dokonanie inwestycji na danym obszarze powinien uwzględnić [Komorowski 2006, s. 21]:

1) uwarunkowania pozwalające na prowadzenie działalności w danym regionie (np. zasobność kraju w surowce, zasoby pracy i dostępność kapitału),

2) relacje przedsiębiorstwo-otoczenie (m.in. specyfikę branży, analizę konkurencji, możliwości zaopatrzenia i zbytu, bariery wejścia i wyjścia),

3) warunki instytucjonalno-prawne.

Autor wskazuje także czynniki obiektywne, które determinują atrakcyjność inwestycyjną danego regionu [Komorowski 2006, s. 22]:

1) ogólny poziom rozwoju: jakość życia ludności, poziom infrastruktury technicznej i społecznej (infrastruktura transportowa, telekomunikacyjna, technologiczna, energetyczna, ilość i jakość ośrodków naukowych), poziom kształcenia, służba zdrowia, dostępność źródeł zaopatrzenia i usług towarzyszących prowadzonej działalności,

2) dynamika rozwoju gospodarczego: stan koniunktury, rozmiary realizowanych w danym kraju inwestycji, działania władz lokalnych na rzecz rozwoju przedsiębiorczości,

3) relacje popytu i podaży na danym rynku - czynnik ten pozwala na określenie chłonności rynku, atrakcyjności oferowanych produktów i usług, poziomu i struktury konsumpcji, zapotrzebowania na produkty lokalne i zagraniczne, wielkości i charakteru konkurencji, możliwości rozwoju danej branży itd.,

\footnotetext{
${ }^{1}$ Szerzej w [Porter 1980].
} 
4) uwarunkowania demograficzno-społeczne, m.in.: dostępność specjalistów w danej branży oraz kadry menedżerskiej, kwalifikacje, wykształcenie i doświadczenie pracowników lokalnych, możliwości aklimatyzacyjne pracowników z zewnątrz, znajomość uznawanych w danym kraju systemów wartości, kultury, religii i zwyczajów w nim panujących, poziom przestępczości, postawy, konflikty społeczne, poziom, charakter i przyczyny ruchów migracyjnych,

5) infrastruktura: dostępność źródeł finansowania, możliwości obsługi logistycznej, dostępność i ceny czynników wytwórczych,

6) obsługa przedsiębiorców przez podmioty publicznoprawne: stosunek do inwestorów zagranicznych, rodzaje stosowanych zachęt inwestycyjnych, ulg, możliwości korzystania z funduszy rozwoju regionalnego i dotacji, współdziałanie z podmiotami publicznymi, poziom korupcji, możliwości rozwiązywania ewentualnych sporów, przejrzystość przepisów prawnych, poziom biurokracji itp.

Należy podkreślić, że liczba i wartość dokonywanych na danym obszarze bezpośrednich inwestycji zagranicznych zależy od jego atrakcyjności inwestycyjnej. Im wyższa, tym więcej kapitału napływa do danego kraju. Jednocześnie wraz z napływem kapitału rosną możliwości dalszego rozwoju, m.in. w postaci szybszego wzrostu gospodarczego, zmniejszenia poziomu bezrobocia, rozwoju przedsiębiorczości, zmian społecznych i demograficznych oraz możliwości wprowadzania reform i przekształceń strukturalnych. Poprawa poziomu rozwoju społeczno-gospodarczego przyczynia się z kolei do poprawy warunków prowadzenia działalności i zwiększenia atrakcyjności inwestycyjnej.

\section{Nowy Jedwabny Szlak a atrakcyjność inwestycyjna krajów ASEAN}

Inicjatywa Nowego Jedwabnego Szlaku składa się z dwóch koncepcji: sieci połączeń lądowych (Silk Road Economic Belt) oraz morskich (Maritime Silk Road). W ich ramach wyznaczono pięć głównych tras łączących Chiny z krajami Azji, Afryki oraz Europy oraz kilkanaście wariantów tras pośrednich. Zaplanowano na nich utworzenie sześciu korytarzy współpracy gospodarczej (rys. 1).

Z racji swojego położenia na skrzyżowaniu najważniejszych szlaków handlowych kraje należące do ASEAN mają kluczowe znaczenie w realizacji koncepcji szlaku morskiego. Ma się on zaczynać w południowo-wschodniej prowincji chińskiej Guandong, a następnie biec wzdłuż wybrzeży Azji Południowo-Wschodniej, przez cieśninę Malakka, Sri Lankę do Oceanu Indyjskiego, stamtąd do portu w Mombasie, wzdłuż Rogu Afryki przez Kanał Sueski do Morza Śródziemnego, skąd może rozdzielić się na inne porty. Istnieje możliwość jego połączenia z trasą lądową w krajach Europy Południowej [Kaczmarski 2015, s. 7-8]. Poza zwiększeniem wymiany handlowej włączenie przez Chiny krajów ASEAN do Inicjatywy Pasa i Szlaku ma także pozwolić na stworzenie trwałej współpracy oraz poprawić chińską pozycję w sporach terytorialnych z tymi krajami. Ochrona szlaków morskich będzie bowiem wymagała zwiększenia obecności chińskich wojsk na spornych wodach. 


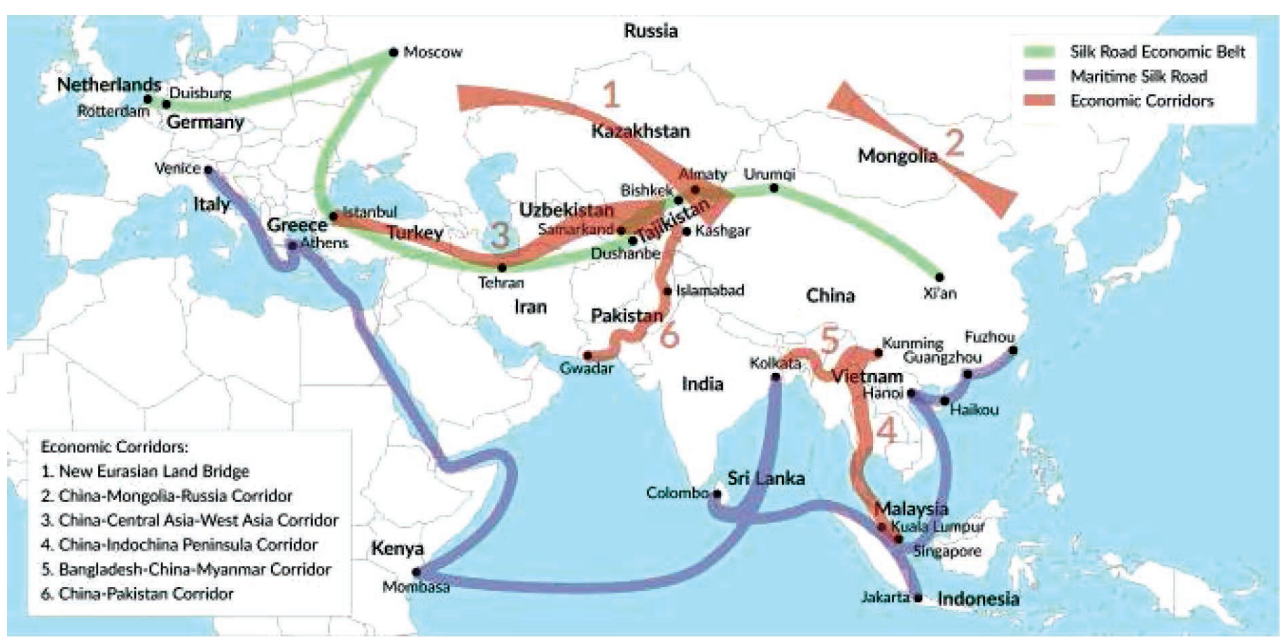

Rys. 1. Chińska Inicjatywa Pasa i Szlaku - korytarze współpracy gospodarczej

Źródło: [https://www.gisreportsonline.com/media/report_images/BRI_6_corridors_2.jpg, stan na 8.03.2019].

Uczestnictwo krajów należących do ASEAN w Nowym Jedwabnym Szlaku ma swoje odzwierciedlenie w wolumenie ich wymiany handlowej oraz rozmiarach bezpośrednich inwestycji zagranicznych lokowanych na ich terytorium. W tabeli 1 zaprezentowano dane pokazujące wartość wymiany realizowanej przez kraje ASEAN w latach 2012-2017 w handlu towarami.

Tabela 1. Wielkość wymiany handlowej krajów ASEAN w latach 2012-2017 - handel towarami

\begin{tabular}{|l|r|r|r|r|r|r|}
\hline \multirow{2}{*}{ Kraj } & \multicolumn{6}{|c|}{ Całkowita wymiana handlowa towarów (w mld USD) } \\
\cline { 2 - 7 } & \multicolumn{1}{|c|}{2012} & \multicolumn{1}{c|}{2013} & \multicolumn{1}{c|}{2014} & \multicolumn{1}{c|}{2015} & \multicolumn{1}{c|}{2016} & \multicolumn{1}{c|}{2017} \\
\hline Singapur & 801,4 & 808,0 & 793,3 & 666,0 & 630,0 & 700,9 \\
\hline Indonezja & 381,7 & 369,2 & 354,2 & 293,0 & 280,8 & 325,8 \\
\hline Malezja & 423,9 & 434,0 & 442,8 & 375,2 & 358,1 & 412,5 \\
\hline Filipiny & 117,4 & 119,1 & 130,8 & 128,8 & 142,2 & 176,1 \\
\hline Tajlandia & 477,3 & 478,2 & 455,5 & 427,1 & 410,0 & 459,5 \\
\hline Brunei & 16,9 & 15,1 & 14,2 & 9,6 & 8,7 & 7,8 \\
\hline Laos & 4,3 & 6,5 & 7,0 & 6,8 & 7,7 & 8,4 \\
\hline Kambodża & 12,8 & 14,9 & 16,4 & 20,4 & 22,4 & 25,6 \\
\hline Wietnam & 227,8 & 264,8 & 293,8 & 327,7 & 351,0 & 424,6 \\
\hline Mjanma & 17,2 & 23,3 & 27,3 & 28,3 & 27,5 & 33,1 \\
\hline ASEAN & 2480,7 & 2533,1 & 2535,3 & 2282,9 & 2238,4 & 2574,3 \\
\hline
\end{tabular}

Źródło: [ASEAN Statistical... 2018, s. 59]. 
Należy zauważyć, że wartość wymiany handlowej towarowej w 2017 r. wzrosła w stosunku do roku 2012 (przed ogłoszeniem OBOR) i była najwyższa w całym analizowanym okresie. Jej całkowita wartość w krajach ASEAN osiągnęła w 2017 r. poziom 2574,3 mld USD. Można przypuszczać, że wynik ten byłby lepszy, gdyby nie znaczny spadek światowych obrotów handlowych w latach 2015-2016. Złożyło się na niego wiele czynników, wśród których do najważniejszych zalicza się: spowolnienie gospodarcze w Chinach, spadające ceny ropy naftowej i innych surowców oraz zmienność kursu walutowego (m.in. aprecjacja chińskiego juana spowodowała, że chiński eksport był droższy na rynkach zagranicznych zmniejszając jego rozmiary) [World Trade Statistical Review 2016, s. 18-20]. Chiny są najważniejszym partnerem handlowym krajów ASEAN (z wyjątkiem wymiany wewnętrznej między członkami Stowarzyszenia) [ASEAN Statistical... 2018, s. 83], zatem problemy gospodarcze Państwa Środka mają bezpośrednie przełożenie na osiągane przez nie wyniki. Pomimo wspomnianego spowolnienia w latach 2012-2017 znacznie wzrosła wymiana usług w krajach należących do ASEAN, osiągająca w 2017 r. poziom 702,6 mld USD (tab. 2).

Tabela 2. Wielkość wymiany handlowej krajów ASEAN w latach 2012-2017 - handel usługami

\begin{tabular}{|l|r|r|r|r|r|r|}
\hline \multirow{2}{*}{ Kraj } & \multicolumn{6}{|c|}{ Całkowita wymiana handlowa usług (w mld USD) } \\
\cline { 2 - 7 } & 2012 & 2013 & 2014 & 2015 & 2016 & 2017 \\
\hline Singapur & 264,4 & 294,2 & 324,4 & 322,1 & 320,4 & 335,5 \\
\hline Indonezja & 57,9 & 58,0 & 57,1 & 53,1 & 53,7 & 57,1 \\
\hline Malezja & 84,0 & 87,0 & 87,2 & 75,0 & 75,7 & 79,3 \\
\hline Filipiny & 34,7 & 39,7 & 46,4 & 52,7 & 55,4 & 61,2 \\
\hline Tajlandia & 95,4 & 106,2 & 100,8 & 104,3 & 111,1 & 121,5 \\
\hline Brunei & 3,1 & 3,1 & 2,7 & 2,3 & 2,2 & 1,8 \\
\hline Laos & 1,3 & 1,8 & 1,9 & 1,9 & 1,9 & 2,0 \\
\hline Kambodża & 4,8 & 5,4 & 6,0 & 6,3 & 6,6 & 7,5 \\
\hline Wietnam & 20,6 & 24,4 & 26,0 & 27,2 & 29,2 & 30,0 \\
\hline Mjanma & 2,4 & 3,1 & 5,3 & 6,2 & 6,3 & 6,7 \\
\hline ASEAN & 568,6 & 622,9 & 657,8 & 651,1 & 662,5 & 702,6 \\
\hline
\end{tabular}

Źródło: opracowanie własne na podstawie [ASEAN Statistical... 2018, s. 125].

Światowe spowolnienie gospodarcze w latach 2015-2016 znalazło swoje odzwierciedlenie także w rozmiarach inwestycji lokowanych w krajach ASEAN. Niemniej jednak udział w Inicjatywie Nowego Jedwabnego Szlaku znacząco wpłynął na wzrost tego wskaźnika. W roku 2012 przed ogłoszeniem OBOR wartość napływu BIZ do ASEAN wynosiła 116,5 mld USD, tymczasem w roku 2017 - aż 137 mld USD. Największym odbiorcą światowych BIZ jest zdecydowanie Singapur. Istotną rolę odgrywają jednak także: Indonezja, Wietnam (którego pozycja w ostatnich latach systematycznie rośnie), a także Malezja, Filipiny i Tajlandia. 
Tabela 3. Wartość inwestycji ulokowanych w krajach ASEAN w latach 2012-2017

\begin{tabular}{|l|r|r|r|r|r|r|}
\hline \multirow{2}{*}{ Kraj } & \multicolumn{7}{|c|}{ Napływ BIZ (w mld USD) } \\
\cline { 2 - 7 } & 2012 & 2013 & 2014 & 2015 & 2016 & 2017 \\
\hline Singapur & 59,8 & 57,7 & 73,5 & 62,7 & 77,5 & 62,0 \\
\hline Indonezja & 19,1 & 18,4 & 21,8 & 16,6 & 3,9 & 23,1 \\
\hline Malezja & 9,4 & 12,1 & 10,9 & 10,2 & 11,3 & 9,4 \\
\hline Filipiny & 2,8 & 3,9 & 5,8 & 5,6 & 8,3 & 10,0 \\
\hline Tajlandia & 12,9 & 15,9 & 5,0 & 8,9 & 3,1 & 9,1 \\
\hline Brunei & 0,9 & 0,7 & 0,6 & 0,2 & $-0,2$ & 0,5 \\
\hline Laos & 0,3 & 0,4 & 0,9 & 1,1 & 1,1 & 1,7 \\
\hline Kambodża & 1,6 & 1,3 & 1,7 & 1,7 & 2,3 & 2,7 \\
\hline Wietnam & 8,4 & 8,9 & 9,2 & 11,8 & 12,6 & 14,1 \\
\hline Mjanma & 1,4 & 2,6 & 0,9 & 2,8 & 3,0 & 4,3 \\
\hline ASEAN & 116,5 & 121,7 & 130,3 & 121,7 & 122,8 & 137,0 \\
\hline
\end{tabular}

Źródło: [ASEAN Investment... 2018, s. 5].

Wśród największych dawców kapitału w postaci BIZ w regionie Azji Południowo-Wschodniej dominują inwestorzy wewnętrzni (pochodzący z innych krajów ASEAN). Ich udział w BIZ lokowanych w regionie w 2017 r. wyniósł 19,4\%. Drugie miejsce zajęli w tym rankingu inwestorzy z Japonii $(9,6 \%)$, a trzecie - inwestorzy z Chin $(8,2 \%)$. Warto jednakże podkreślić, że struktura pochodzenia kapitału uległa znacznym zmianom w stosunku do roku 2016, kiedy to drugą pozycję po inwestorach wewnętrznych zajmowały Stany Zjednoczone, których udział w inwestycjach w tym regionie wynosił $15,3 \%$, tymczasem w $2017 \mathrm{r}$. spadł do poziomu zaledwie $3,9 \%$. Jest to ciekawa tendencja, biorąc pod uwagę fakt, że w ostatnich latach japońskie i amerykańskie inwestycje $\mathrm{w}$ tym regionie dominowały nad inwestycjami chińskimi, mimo że wartość tych ostatnich systematycznie rośnie.

Wzrost chińskich inwestycji w ASEAN wynika w znacznym stopniu z działań podejmowanych $w$ ramach Inicjatywy Pasa i Szlaku. Skoro kraje ASEAN mają odgrywać kluczową rolę w Szlaku Morskim, konieczna jest rozbudowa w szczególności infrastruktury portowej, ale także powiązań lądowych oraz sieci energetycznych, które pozwolą na obsługę zwiększonych połączeń morskich. Chiny jako inicjator Nowego Jedwabnego Szlaku wiążą duże nadzieje z krajami Azji Południowo-Wschodniej, zatem (traktując je jako jedną gospodarkę) lokują w nich najwięcej inwestycji.

$\mathrm{Na}$ rysunku 2 zaprezentowano udział chińskich inwestycji podejmowanych w krajach ASEAN w latach 2013-2018 we wszystkich chińskich inwestycjach w ramach Nowego Jedwabnego Szlaku, a także łączną wartość wszystkich chińskich inwestycji w krajach ASEAN w ramach OBOR od momentu jej ogłoszenia. Co prawda, w roku 2018 nastąpił ich znaczny spadek, jednak szacuje się, że łączna 


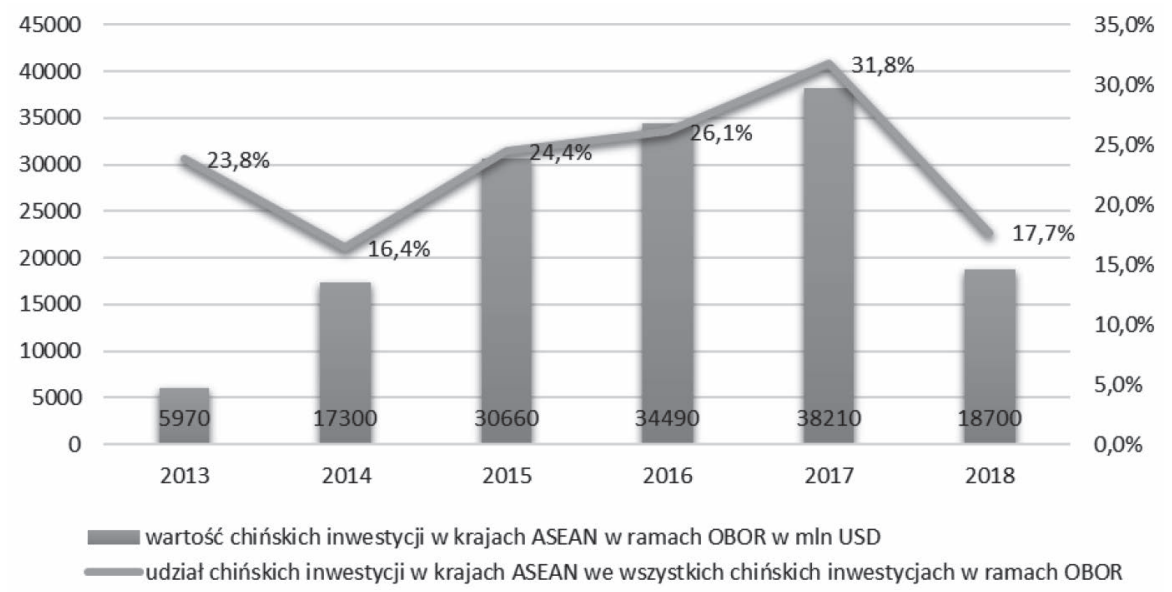

Rys. 2. Chińskie inwestycje w ASEAN w ramach OBOR w latach 2013-2018

Źródło: opracowanie własne na podstawie [Chin Global... 2019].

wartość chińskich inwestycji w latach 2016-2030 ma wynieść aż 3,1 bln USD [Qin, Cao]. Warto podkreślić, że w roku 2017 chińskie inwestycje w ASEAN stanowiły aż 31,8\% kapitału ulokowanego przez ten kraj w państwach zaangażowanych w OBOR.

Jak już wspomniano, najwięcej chińskich inwestycji w krajach ASEAN w ostatnich kilku latach to inwestycje infrastrukturalne. Do najistotniejszych z nich zaliczyć należy m.in. budowę elektrowni wodnej Kayan River w Indonezji, której całkowita wartość ma osiągnąć poziom ok. 17,8 mld USD [POWERCHINA Signed...]. Dużą wartość kapitału - ok. 13,4 mld USD - pochłonęła już także budowa pierwszego w Malezji parku przemysłowego zlokalizowanego w pobliżu portu Kuantan nad Morzem Południowochińskim, którego terminal głębokowodny także został rozbudowany celem podwojenia jego przepustowości przy znacznym udziale chińskich inwestorów. Park przemysłowy przyciągnął w szczególności inwestorów z branż energooszczędnych, wykorzystujących technologię przyjazną środowisku naturalnemu, oraz producentów sprzętu wysoko zaawansowanego technologicznie [Ng]. Działania podejmowane przez Chiny w krajach ASEAN w ramach OBOR mają również na celu rozbudowę infrastruktury drogowej i kolejowej. Jednym z flagowych projektów w ramach OBOR jest budowa w Malezji sieci kolejowej East Coast Rail Link, której wartość miała osiągnąć nawet 20 mld USD. Niestety malezyjskie władze po objęciu stanowiska premiera przez Mahathira Mohamada w 2018 r. zawiesiły prace i prowadzą obecnie rozmowy z Chinami w celu ich wznowienia najprawdopodobniej na nieco mniejszą skalę. Nowy premier w obawie przez zbytnim zadłużeniem Malezji wstrzymał tymczasowo chińskie inwestycje o łącznej wartości ok. 23 mld USD [Malaysia and China...]. Strona chińska liczy jednak na to, że nego- 
cjacje z malezyjskim rządem zakończą się sukcesem i uda się wznowić planowane działania. Jest to bowiem dla nich nie tylko problem ekonomiczny, ale także wizerunkowy - Chiny obawiają się, że sprzeciw Malezji może podważyć zdanie innych krajów członkowskich o słuszności całej inicjatywy. Należy przy tym zauważyć, że wszystkie kraje działające $\mathrm{w}$ ramach OBOR muszą zaangażować w podejmowane inwestycje często znaczne kwoty kapitału. Aby zachęcić przywódców do przystąpienia do inicjatywy, w 2014 r. stworzono Fundusz Nowego Jedwabnego Szlaku o wartości 40 mld USD, 100 mld USD przeznaczono na Nowy Bank Rozwoju oraz dodatkowo zasilono kapitał Azjatyckiego Banku Inwestycji Infrastrukturalnych AIIB (w których Chiny posiadają 30\% udziałów) o 100 mld USD na realizację projektów w ramach OBOR. Najważniejszym celem AIIB jest wsparcie biedniejszych krajów Azji w inwestycjach infrastrukturalnych. Pieniądze te trafić mogą zatem w dużej części do krajów CLMV (Kambodża, Laos, Mjanma, Wietnam). Podczas Forum Pasa i Szlaku, które odbyło się w dniach 14-15 maja 2017 r. w Pekinie, Prezydent Xi zapowiedział m.in. zwiększenie Funduszu Nowego Jedwabnego Szlaku o 14,5 mld USD [Yiming 2017].

Analizując zagadnienie atrakcyjności inwestycyjnej ASEAN jako ugrupowania, należy zdecydowanie podkreślić znaczenie Singapuru, który jest najbardziej rozwiniętym gospodarczo państwem regionu i przyciąga najwięcej kapitału zagranicznego. Jako centralny węzeł Azji Południowo-Wschodniej Singapur jest trzecim, za Hongkongiem i Londynem, rynkiem offshore na świecie. Kraje ASEAN, jako szybko rozwijające się gospodarki, mają bardzo duże potrzeby kapitałowe na finansowanie projektów infrastrukturalnych, które znacznie przekraczają możliwości ich rządów. Według władz Singapuru około $60 \%$ projektów infrastrukturalnych ASEAN skorzystało z finansowania lub usług doradczych singapurskich banków. Ponadto ponad 50 banków międzynarodowych i regionalnych ma swoje oddziały w Singapurze. Firmy emitujące obligacje mogą tam skorzystać z usług oferowanych przez międzynarodowych prawników, księgowych i agencje ratingowe. Singapur ma dojrzały system finansowy i bogate doświadczenie w planowaniu i zarządzaniu kapitałem. Jest to również ważny punkt tranzytowy dla chińskich przepływów inwestycyjnych do krajów ASEAN. Prawie jedna trzecia chińskich inwestycji w krajach BRI odbywa się za pośrednictwem Singapuru, a dwie trzecie projektów infrastrukturalnych w Azji Południowo-Wschodniej planują zespoły finansowe z tego kraju. Singapur posiada także uznany i renomowany system sądownictwa, który odgrywa ważną rolę w zapobieganiu ryzyku inwestycyjnemu i rozwiązywaniu transgranicznych sporów handlowych [Qin, Cao, s. 20-22].

\section{Zakończenie}

Inwestycje podejmowane dotychczas w krajach ASEAN w ramach BRI mają na celu przede wszystkim rozwój infrastruktury transportowej. Napływ znacznej ilości kapitału zagranicznego przekłada się z kolei na rozwój społeczno-gospodarczy 
tych krajów. Średni poziom PKB per capita w krajach ASEAN wzrósł z 3951 USD w 2012 r. do 4308 USD w roku 2017 r. (przy czym poziom tego wskaźnika w Brunei znacznie się obniżył: z 47648 USD do 28986 USD w tym okresie, co jest w największym stopniu spowodowane wyczerpywaniem zasobów ropy naftowej i gazu stanowiących podstawę rozwoju tej gospodarki) [ASEAN Statistical... 2018, s. 45]. Wszystkie kraje należące do ASEAN w latach 2012-2017 poprawiły swój wskaźnik rozwoju społecznego (HDI), jednakże najbiedniejsze kraje ASEAN wciąż zajmują bardzo odległe miejsca w światowym rankingu (w 2017 r. na 189 badanych krajów Mjanma zajmowała miejsce 148, a Laos uplasował się na 139 miejscu; najlepszą 9. lokatę uzyskał Singapur) [Human Development... 2018].

Wśród rankingów kompleksowo badających atrakcyjność inwestycyjną gospodarek większość krajów ASEAN zanotowała wzrost swojej pozycji w roku 2018 w stosunku do wyników osiąganych przed ogłoszeniem OBOR (tab. 4).

Tabela 4. Atrakcyjność inwestycyjna krajów ASEAN w świetle międzynarodowych rankingów

\begin{tabular}{|c|c|c|c|c|c|c|}
\hline \multirow[t]{2}{*}{ Kraj } & \multicolumn{2}{|c|}{$\begin{array}{l}\text { Global FDI Country } \\
\text { Attractiveness Index }\end{array}$} & \multicolumn{2}{|c|}{$\begin{array}{l}\text { Global Opportunity } \\
\text { Index }\end{array}$} & \multicolumn{2}{|c|}{$\begin{array}{c}\text { Global Competitiveness } \\
\text { Report }\end{array}$} \\
\hline & 2013 & 2018 & 2012 & 2018 & 2012 & 2018 \\
\hline Singapur & 9 & 6 & 1 & 2 & 2 & 2 \\
\hline Indonezja & 63 & 68 & 73 & 66 & 50 & 45 \\
\hline Malezja & 23 & 31 & 23 & 24 & 25 & 25 \\
\hline Filipiny & 64 & 70 & 105 & 84 & 65 & 56 \\
\hline Tajlandia & 42 & 42 & 39 & 27 & 38 & 38 \\
\hline Brunei & \multicolumn{2}{|c|}{ nieklasyfikowany } & \multicolumn{2}{|c|}{ nieklasyfikowany } & 28 & 62 \\
\hline Kambodża & 89 & 82 & 113 & 75 & 85 & 110 \\
\hline Laos & \multicolumn{2}{|c|}{ nieklasyfikowany } & nieklasyfikowany & 99 & nieklasyfikowany & 112 \\
\hline Wietnam & 61 & 56 & 77 & 60 & 75 & 77 \\
\hline Mjanma & \multicolumn{2}{|c|}{ nieklasyfikowany } & \multicolumn{2}{|c|}{ nieklasyfikowany } & \multicolumn{2}{|c|}{ nieklasyfikowany } \\
\hline
\end{tabular}

Źródło: opracowanie własne na podstawie [A Global FDI...; Global Opportunity Index 2015; 2018; The Global Competitiveness Report 2012; 2018].

Przedstawione w tab. 4 dane potwierdzają, że największym zainteresowaniem inwestorów spośród krajów należących do ASEAN cieszy się Singapur. Co prawda wyniki Global Opportunity Index świadczą o tym, że kraj ten stracił pozycję lidera na rzecz Hongkongu, jednak można tłumaczyć to faktem, że Hongkong to specjalny region administracyjny Chin oraz najistotniejsze centrum finansowe w regionie obsługujące większość chińskich inwestycji. Poza Singapurem za najbardziej atrakcyjne wśród krajów ASEAN uznawane są Malezja oraz Tajlandia. Pozostałe państwa zajmują odległe miejsca w przedstawionych rankingach (co świadczy o ich niskiej atrakcyjności inwestycyjnej), choć w wielu przypadkach poprawiają się ich noto- 
wania (szczególnie dotyczy to tych słabiej rozwiniętych). Na przykład Kambodża i Wietnam polepszyły znacznie swoje pozycje w rankingach Global FDI Country Attractiveness Index oraz Global Opportunity Index. Niestety oba kraje zanotowały spadek pozycji w rankingu Global Competitiveness Report. Należy jednak pamiętać, że atrakcyjność inwestycyjna jest pojęciem węższym niż konkurencyjność gospodarek, jest jedynie jednym z jej elementów, zatem na wynik kraju w przypadku tego wskaźnika, poza postrzeganiem w oczach inwestorów zagranicznych, wpływa także wiele innych elementów. Chęć poprawy miejsc badanych krajów w międzynarodowych rankingach jest jedną z przesłanek do podejmowania inicjatyw zachęcających przedsiębiorców do lokowania działalności na ich obszarze, w tym udział w OBOR.

Reasumując, można stwierdzić, że ogłoszona w 2013 r. Inicjatywa Nowego Jedwabnego Szlaku jest istotną przyczyną zwiększonej liczby inwestycji lokowanych w ostatnich latach w krajach zrzeszonych w ramach Stowarzyszenia Narodów Azji Południowo-Wschodniej. Podejmowane w nich działania, przy znacznym udziale chińskiego kapitału, mają na celu podniesienie poziomu infrastruktury w tym regionie. Ich wymiernym efektem ma być zwiększenie wolumenu wymiany handlowej oraz podniesienie atrakcyjności inwestycyjnej całego regionu.

\section{Literatura}

A Global FDI Country Attractiveness Index, 2018, http://www.fdiattractiveness.com/ranking-history/, stan na 18.03.2019.

ASEAN Investment Report 2018 - Foreign Direct Investment and the Digital Economy in ASEAN, 2018, ASEAN Secretariat, UNCTAD, Dżakarta.

ASEAN Statistical Yearbook 2018, 2018, ASEAN Secretariat, Dżakarta.

Behrendt P., 2017, Morski Jedwabny Szlak, Analiza Centrum Studiów Polska-Azja, nr 13, www.polska-azja.p1/wp-content/uploads/2017/08/analiza-cspa-13.pdf.

China Global Investment Tracker, American Enterprise Institute, Waszyngton 2019, http://www.aei. org/china-global-investment-tracker/, stan na 28.03.2019.

Czech-Rogosz J., 2012, Atrakcyjność inwestycyjna RFN - wybrane zagadnienia, [w:] Noga M., Stawicka M.K. (red.), Globalizacja a konkurencyjność w gospodarce światowej, CeDeWu, Warszawa.

Dunning J.H., 2000, The eclectic paradigm as an envelope for economic and business theories of MNE activity, International Business Review, vol. 9(2).

Gawlikowska-Hueckel K., Umiński S., 2000, Ocena konkurencyjności województw, Polska Regionów, nr 12, Instytut Badań nad Gospodarką Rynkową, Gdańsk.

Global Opportunity Index, 2015, 2018, Milken Institute, http://www.globalopportunityin dex.org/opportunity.taf?page $=$ rankings.

Gołaszewska-Kaczan U., 2006, Partnerstwo publiczno-prawne a atrakcyjność regionu, [w:] Kopczuk A., Proniewski M. (red.), Atrakcyjność inwestycyjna regionu, Wydawnictwo Wyższej Szkoły Finansów i Zarządzania w Białymstoku, Białystok.

https://www.gisreportsonline.com/media/report_images/BRI_6_corridors_2.jpg.

Human Development Report 2018, http://hdr.undp.org/en/data, stan na 25.03.2019.

Kaczmarski M., 2015, Nowy Jedwabny Szlak: uniwersalne narzędzie chińskiej polityki, Komentarze OSW, nr 161. 
Kalinowski T. (red.), 2005, Atrakcyjność inwestycyjna województw i podregionów Polski 2005, Instytut Badań nad Gospodarką Rynkową, Gdańsk.

Kokkinou A., Psycharis I., 2005, Foreign Direct Investment and Regional Attractiveness in Southeastern European countries, paper submitted for the 45th European Congress of the Regional Science Association, Amsterdam, www-sre.wu-wien.ac.at/ersa/ersaconfs/ersa05/papers/382.pdf.

Komorowski J., 2006, Kształtowanie poziomu atrakcyjności inwestycji w polityce rozwoju regionalnego, [w:] Kopczuk A., Proniewski M. (red.), Atrakcyjność inwestycyjna regionu, Wydawnictwo Wyższej Szkoły Finansów i Zarządzania w Białymstoku, Białystok.

Malaysia and China Finalize Railway Deal Rework, China Economic Review, https://chinaeco nomicreview.com/malaysia-and-china-finalize-railway-deal-rework/

$\mathrm{Ng}$ E., The Rise of Chinese FDI into ASEAN, https://americas.nikkoam.com/articles/2017/10/ the-rise-of-chinese-fdi-into-asean?nk-route, stan na 28.03.2019.

Porter M.E., 1980, Competitive Strategy, Free Press, Nowy Jork.

POWERCHINA Signed Joint Development Agreement for the Kayan River 1-5 Cascade Hydropower station in Indonesia, Belt and Road Energy Cooperation, http://obor.nea.gov.cn/detail2/2631.html.

Qin R., Cao Z., ASEAN Opportunities on Belt and Road, Research Digest, Nus Business School China Business Centre, https://bschool.nus.edu.sg/images/CBC/issues-and-insights/asean-opportuni ties/asean-opportunities-on-belt-and-road.pdf.

Stawicka M., 2007, Atrakcyjność inwestycyjna Polski, CeDeWu, Warszawa.

The Global Competitiveness Report, 2012, 2018, World Economic Forum, www.weforum.org, stan z 18.03.2019.

Vision and Actions on Jointly Building Silk Road Economic Belt and 21st-Century Maritime Silk Road, 28.03.2015, http://en.ndrc.gov.cn/newsrelease/201503/t20150330_669367.html.

Witkowska J., 1996, Bezpośrednie inwestycje zagraniczne w Europie Środkowowschodniej. Próba interpretacji na gruncie bezpośrednich inwestycji zagranicznych i teorii integracji, Wydawnictwo Uniwersytetu Łódzkiego, Łódź.

World Trade Statistical Review 2016, WTO, https://www.wto.org/english/res_e/statis_e/wts2016_e/ wts2016_e.pdf, stan na 18.03.2019.

Yiming S., 2017, China's Belt and Road Initiative: Opportunities and Risks for Singapore and ASEAN, Marsh \& McLennan Companies Report, https://www.marsh.com/ph/insights/re search/china-beltroad-initiative-opportunities-and-risks-for-singapore-and-asean.html, stan na 15.03.2019. 